\title{
A Vision for a Bewildering Time
}

\author{
Commencement Address at \\ Washington \& Jefferson College
}

May 18, 2007

On the occasion of receiving an honorary doctorate from Washington \& Jefferson College in Washington, PA, Beerman faced the challenging task of delivering the commencement address. He drew on a mix of religious and literary sources to lay out a familiar set of dichotomies: between darkness and light, a culture of materialism and a state of poverty, and greed and love. His message to the Washington \& Jefferson undergraduates was not to rest content dwelling in these opposing tendencies, but to seek out the interconnectedness of life. It was especially in great works of art that one could most readily grasp this interconnectedness. A sense of connection, in turn, lends us a measure of "ardor and courage" in engaging with the world.

I am so grateful to Dr. Tori Haring-Smith for giving me the opportunity to be with you today. With this invitation she has allowed me to return to a geography I have not visited for at least eighty years. I was a boy of six when l accompanied my father, a traveling salesman, as he made his [way] through the small towns of this area.

And thinking of my father reminds me of one of the valuable principles I learned from him when I was very young, one so easily forgotten on occasions like this one. For I still remember when he took a baseball bat and placed it in my hands, showed me how to swing it and then, very solemnly declared, "Now son, you must remember to keep your eye on the ball." Ever since, often failing, I have tried to make those immortal words my guide, and I offer them to you. This means that our task is to consider always what is taking place, to focus, center on that, lend ourselves to it, lean into it, permit ourselves to become servant to it.

So what is the ball here that I must strive to keep my eye on today? Is it not really something very clear and simple? Is it not that some wonderfully impressive 
young men and women are about to take their place in the great processional of those who throughout the ages have wished to advance the cause of human learning? And at such a moment, custom dictates that an older one step forward to address them. And the message to be delivered, no matter what its apparent form or content, the message is always the same. The old one faces the young and says: Blessed is the God who has kept us alive and sustained us and brought us to this joyful time. For we look at you and we feel the swarming of youth and hope and voices, and the generations to come, the thing others will see. We want you to be armed with hope, and to be awake to the consciousness of the good, the beauty, the tenderness, the passion, the gaiety, the rhythm, the music of life. We want you to be awake to all that is sweet and noble.

As for us, the world we have helped to fashion for you is a dark place, and we older ones often fumble in it. We confess to you, paraphrasing the words of James Agee, that our desire and our faith delude us into wrong visions and attributions; that the best of our knowledge is but the shade and shape of a dream, and full of pretense. Nevertheless, we have faith in you, and we pray that your eyes and your hearts be honest and lovely and a little clearer than ours. We embrace you with our love and our prayers, and we welcome you into the company of those to whom no acceptable answer has yet been given. We welcome you to the company of those who wish to sing God's song in the land.

The voice trails away. It is enough to say that. Let the ceremony continue. Let the commencement come. It is enough, is it not?

Ah, but you know as well as I that that doesn't always work for members of the clergy of any persuasion (did you imagine that a rabbi would be any different?) and at my age the eye is not so sharp to see the ball, the heart melts just a little with gratitude and nostalgia-a most incendiary mixture. And I see those windows here, windows that connect us to the real world, to remind us that outside is that crazy, mixed-up complicated brutal world we shall have to live and work in. And there, lurking just beyond those windows, waiting for us, are some haunting questions: "How shall we sing God's song in such a strange land?" How shall we know the good and the tenderness, when we live on a precarious planet where a small affluent elite perches fearfully on the top of three continents of hungry people? How shall we know beauty, when there are so many humiliated? How shall we experience the rhythm, the music of life?

You and I, as Lewis Lapham has written, are or will be members of the possessing classes, those who are able to recline at their ease among computers and cellular phones. On the other side of the walls, in the desolate slums, in the third and fifth worlds, the mass of poor, the terminally impoverished, tear at one another for bones. Most of us here agree, I am certain, on the moral unacceptability of the persistent and growing "savage inequality" in income, in education, in opportunity, here and throughout the world, whether caused by discrimination or economic policy. But 
there may be some among us, and certainly many out there, who accept this world as it is, as if it were given to Moses on Mt. Sinai or were the ultimate expression of the inexorable process of evolution. What's mine is mine. I haven't stolen it. It is a privilege I have earned or deserved. In this view, as Peter Marin said, we are in our proper place; others are in theirs. We may even bemoan their fate or even try to do something to change it, but in essence it has nothing to do with us. Nothing to feel guilty about. The self, fulfilling the self, even the quest for self-esteem, even the yearning for certain kinds of spirituality, here replaces everything else. The other just disappears. Disappears in the morning coffee. Disappears in the business news, where you might learn of some cautions about the booming economy and of the wisdom and the courage and the efficiency of the leadership of this or that corporation, trimming its costs by the elimination of thousands of employees.

"You can't eat an orange and throw the peel away. A man is not a piece of fruit," Willie Loman cries out, in Death of a Salesman.

"He's not the finest character that ever lived," his wife Linda says to their sons. "But he's a human being and a terrible thing is happening to him. So attention must be paid."

A spirit is characterized not only by what it does, but no less by what it permits, what it forgives, what it beholds in silence.

We know that we have been inhabiting an age brimming with cruelty and violence and mendacity, where human beings, even the best of them, act in what could kindly be called morally ambiguous ways, and often in the name of the highest ideals and noblest visions. We have been stunned and staggered by the violence. Who of us has not felt fear and uncertainty, who of us has not had feelings of shock, sorrow, loss, anger, and a heightened sense of our own vulnerability?

Did something go wrong at the very beginning?

The poet Joseph Pintauro thought so, and described it this way:

Something went wrong

In the garden.

Eve said to $\{$ Cain $\}$ her first

Born son, "get over

Here or I'll break

every bone

in your body.

And Adam said, "do what your mother tells you."

And the boy said, "someday."

So here we are, you and I. We have been taught from the most ancient times, long before the insights of Sigmund Freud, or the modern adaptations and departures from his thought, that God created us human beings with a cluster of contradictory drives and hungers - the impulses of greed and envy, and mutual hatred. The ability to tear the world apart. The power to invent war and tyranny. 
But we have also been endowed with another set of impulses. The ones that draw us toward one another in connection, in community, in love. "The ones that helped us discover liberty, equality, fraternity, and though they remain unrealized, we have labored our way toward them" (Peter Marin, Freedom and Its Discontents). We are not expected to be saints, to achieve the unattainable. The greatest of our Biblical heroes, in the Hebrew Bible, what Christians call the Old Testament, every one of them, was flawed, and the best of us as well. Are we forever condemned to be the prisoner of the balance of power as it presently exists between the two warring impulses within us? The one future beautiful fragile and humble truth that can bring us all to a better way of being is in guarding and cultivating the awareness that whatever value we have has come to us because of the accomplishment of others, the living and the dead. The other is always there, always present in our lives. We can hear it in our voices-does it make you suspicious that you speak a language that was invented by dead people?-you can see it in the color of your eyes. Other is always there, even when you are alone, a book on the shelf, a table, a bed, a chair reminds you that other is always there. It's the hands of others, always the hands of others that make our lives possible. The hands of others lift us from the womb, nurture us when we are most weak and vulnerable. The hands of others weave the clothes, build our homes, the hands of others bring pleasure to our bodies in moments of passion, and ultimately for us all, it will be the hands [of] others that lower [us] into the grave.

We, and all human beings, need a sense of our own individual, private integrity, something not meant to be breached, or assaulted, or violated by others. That is the basis of whatever dignity we possess. The right to be ourselves in solitude-that is what fires creation and discovery. And that is what is always under assault. For we are born into a world we have not made, a world fashioned by other people, and we must, if we are to become ourselves, turn that world into our own.

But we also need the other pole of human need and desire. We need to lose our sense of self, to be part of something larger than ourselves, sometimes in moments of great passion, and that is what is the basis of religion and sex and politics and society, that is what it means to experience that exquisite sense of what one human being owes to another, what one human being can mean to another.

Do we not wish to see and to feel the interconnectedness between all things and to be an instrument of that interconnectedness? Is that not the divine part of ourselves?

I shall always remember what the poet Ann Lauterbach once wrote, some of which I paraphrase: When choices are displayed in the service of the possibility of meaning, in the making of objects of art (for example) we call the results, beautiful. That is, we stand before a painting of Van Gogh or Claude Monet, or we read a poem of Robert Pinsky or Amichai, or we listen to the music of Bach or Beethoven or Mahler, and we say, this is beautiful. "But what we are really announcing is our pleasure and gratitude in the choices the artist has made. We recognize something 
in how one stroke of the brush brushes up against another stroke of the brush; how one note moves toward and away from the next in an astounding sequence; how one word attaches itself to another and to another and to another until something that has to do with all the words separately, gathers into a connection which allows us, which invites us, [which incites us] to experience the meaning of meaning."

Is that not what we are seeking to do and to teach: To see and to feel the union, the connectedness, the beauty of it all-in the marvel of human conscience, in the structure of our bodies and our imaginations and our passions, in all the disparate parts of our lives, in the ties of humanity itself that link us to one another?

This is a vision that can bring ardor and courage to visions of the world, a reaffirmation of our sometimes fragile belief that this world, for all of its cynicism and its suffering, for all of its barbarism and stupidity and anguish, is also a place where change is possible, where love and human will can be transforming. In this endeavor there is no guarantee of victory, but there is a choice: one either collaborates with the enemy-with whatever is, whatever is miserable, or inhumane, with whatever is unjust, with whatever demeans the life of any human being, even those we call our enemies - or one joins the resistance, and insists on being among those who strive to diminish the store of insult and agony in the world, insisting on being among those who dare to believe that every woman, man, child is a disclosure of the divine.

And this comes to you with a wish, a yearning, a prayer, one I discovered in the Library of Congress while prowling around on the Internet, a fragment of a poem in Walt Whitman's own hand: "uncage in my heart a thousand new strengths, and unknown ardors, and terrible ecstasies."

That indeed is what I wish for you.

Blessed are the parents who bore these young people and together with wives and husbands and friends and significant others cajoled, threatened, nudged, [and] lovingly encouraged them to reach this day.

Blessed are the teachers for the enormous power of their faith in the worth of what they do, which makes it possible for them to do so much when the reward is often so ambiguous. Blessed are they for their exquisite patience, for their stubbornness, and for the persistence of their belief in ideas.

Blessed are the students for their laughter, for not giving up, for their courage in overcoming all resistances to learning. Bless them even more with the wisdom to reexamine everything they have learned.

Yes, we have faith in you, and we pray that your eyes and your hearts be honest and lovely and a little clearer than ours. We embrace you and welcome you into the company of those who wish to sing God's song in the land.

\section{COMMENTARY BY PROFESSOR DAVID ELLENSON}

As I write these words reflecting upon this address that Leonard delivered to the graduates of Washington \& Jefferson College, the 2016 American presidential 
campaign is raging. I have little doubt that if he were alive, Leonard would be a supporter of Senator Bernie Sanders. The calls by the Vermont senator for a redress to the plague of societal inequality that mars our nation echo the sentiments and commitments Leonard expressed throughout his lifetime as well as in this speech. The contemporary context only highlights how prescient and prophetic Leonard was when he uttered these words. By reminding the students that he and they were members of the "possessing classes," Leonard challenged them to think about how they would respond to their privileged position. As Leonard stated, who we are as persons is characterized by what we permit, what we forgive, what we behold in silence. Inaction evokes human responsibility as much as the deeds we perform.

Even as Leonard congratulated his listeners on their achievements, he called upon the audience to remember the grandeur that can mark the human spirit. $\mathrm{He}$ emphasized that the miracle of human existence is the miracle of the moral in the human being. The aesthetics of his rhetoric and the sweep of sources he cited to make this point remind us just how literate and inspiring as well as challenging Leonard always was. His ability to be all these things simultaneously was a rare and precious gift, and it makes me realize all the more how much our world is impoverished by the loss of his physical presence. However, his voice continues to cry out in this speech, reminding us that it is we who must mold community and shape the world. It is a message as vital today as when he delivered it in 2007. 